\title{
Pemberian Air Minum Dan Peers Effect Terhadap Perilaku Konsumsi Soft Drink Remaja
}

\author{
Nurwafiah Marda ${ }^{1 *}$ \\ ${ }^{1}$ Program Studi Tadris IPA, Fakultas Ilmu Tarbiyah dan Keguruan, IAIN Ambon \\ *E-mail: nurwafiahmarda@iainambon.ac.id
}

\begin{abstract}
Abstrak: Konteks sosial dan lingkungan sangat berpengaruh dalam pembentukan perilaku dan kebiasaan individu. Sekelompok anak memiliki kebiasaaan yang sama karena mereka adalah subjek dari tekanan lingkungan yang sama misalnya tetangga, peraturan sekolah, atau status sosial ekonomi. Masa remaja merupakan periode rentan untuk mengadopsi kebiasaan yang tidak sehat dan akan berpengaruh terhadap keterpaparan penyakit kronis dikehidupan nantinya. Tujuan Penelitian: Diketahuinya pengaruh intervensi teman sebaya dan penyediaan air minum dalam perubahan perilaku konsumsi soft drink pada remaja. Metode Penelitian: Penelitian ini adalah penelitian eksperimen faktorial dengan desain $2 \times 2$ yaitu 2 variabel bebas dengan 2 level perlakuan. Teknik Sampling menggunakan Randomized Sampling, instrumen penelitian kuesioner, analisa data menggunakan Uji Kruskall Wallis, Pos Hoc Kruskall Wallis dan Uji Friedman. Penelitian dilaksanakan di Kabupaten Bone dengan 99 responden berusia 1315 tahun Hasil: Intervensi teman sebaya tidak memiliki pengaruh terhadap penurunan konsumsi soft drink namun berpengaruh dalam meningkatkan jumlah konsumsi air. Sedangkan intervensi penyediaan air minum berpengaruh terhadap penurunan konsumsi soft drink tetapi tidak meningkatkan konsumsi air minum. Intervensi teman sebaya dan penyediaan air minum berpengaruh dalam menurunkan konsumsi soft drink dan tidak berpengaruh dalam meningkatkan konsumsi air.Ketik abstrak bahasa Indonesia di sini. Isi abstract atau abstrak menggunakan fonta Times New Roman 12. Abstrak terdiri atas: pokok permasalahan, tujuan, metode, hasil, dan kesimpulan. Abstrak ditulis dalam bentuk satu paragraf, tanpa acuan (referensi), tanpa singkatan/akronim, dan tanpa footnote. Abstrak ditulis bukan dalam bentuk matematis, pertanyaan, dan dugaan. Abstrak bukan merupakan hasil copy paste dari kalimat yang ada dalam isi naskah. Isi abstrak bahasa indonesia maksimal 250 kata.
\end{abstract}

\section{Kata Kunci: Soft Drink, Air Minum, Teman Sebaya}

\begin{abstract}
Social and environmental context is very influential on the formation of individual behavior and habits. A group of children have the same habits because they are subject to the same environmental pressures such as neighbors, school rules, or socioeconomic status. Adolescence is vulnerable periode for adopting unhealthy habits and will affect the exposure to chronic disease in later life. Objective: To determine the
\end{abstract}


effect of free drinking water and peer intervention in changes in consumption behavior of soft drinks in adolescents. Research Methods: This study is an experimental study which is factorial with $2 \times 2$ design that is 2 independent variable with 2 level of treatment. The research samples were selected using randomized sampling, the instruments used for this research were questionnaires, and the data collected were analyzed using Kruskall Wallis, Pos Hoc Kruskall Wallis and Friedman test. This Research was conducted in Bone District with 99 repondents age 13-15. Results: Peer interventions have no effect on the decline in soft drink consumption but are influential in increasing the amount of water consumption. However, free drinking water intervention has an effect on the decrease of soft drink consumption but does not affect the consumption of water. Peer plus free drinking water intervention have an effect on reducing the consumption of soft drinks but have no effect in improving water consumption.

\section{Keywords: Soft Drink, Water Consumption, Peers}

Perubahan lifestyle terutama pada pola makan terus menerus terjadi pada beberapa dekade belakangan ini, menyebabkan ketidakseimbangan asupan energi dan energi expenditure yang mengarah pada overweight dan obesitas(Storey, 2010). Beberapa penelitian menunjukkan bahwa kebiasaan konsumsi minuman tinggi gula/minuman berpemanis seperti soda berkaitan dengan peningkatan resiko kesehatan seperti diabetes, penyakit kardiovaskular,jantung, stroke, obesitas dan kanker pankreas(Sakurai et al., 2014; Wolk, Larsson and Agneta, 2014; Anand et al., 2015; Imamura et al., 2016). Konsumsi soft drink menjadi salah satu perilaku berisiko yang banyak diadopsi oleh remaja di Indonesia. Proporsi perilaku ini berada pada urutan kedua tertinggi setelah perilaku kurang konsumsi buah dan sayur (PUSLITBANG Upaya Kesehatan Masyarakat, 2015).

Setiap peningkatan soft drink sebesar $1 \%$ berhubungan dengan meningkatan overweight per 100 orang. Tahun 2013 Indonesia mengkonsumsi soft drink 0.6 galon per orang per tahun dan memiliki 2,4\% tingkat obesitas (Basu et al. 2013). Berdasarkan hasil survey WHO tentang perilaku berisiko di kalangan remaja usia sekolah (13-18 tahun) menunjukkan bahwa 62,34\% siswa di Indoneseia memiliki kebiasaan konsumsi minuman bersoda setiap hari(CDC Surveillances, 2015).

Perilaku makan sangat dipengaruhi oleh konteks sosial. Perilaku akan berbeda ketika makan sendiri dan makan dengan orang lain. Selain pengaruh teman sebaya, suasana lingkungan seorang individu merupakan faktor yang penting dalam pembentukan perilaku dan kebiasaan. Sekelompok anak memiliki kebiasaaan yang sama karena mereka adalah subjek dari tekanan lingkungan yang sama atau keadaan lingkungan misalnya tetangga, peraturan sekolah, atau status sosial ekonomi. Masa remaja merupakan periode unik, dimana individu mulai mencari kebebasan dari pengaruh orang tua mereka. Individu yang berada dalam periode ini rentan untuk mengadopsi kebiasaan yang tidak sehat yang 
akan mempengaruhi mereka terhadap keterpaparan penyakit kronis dikehidupan nantinya(Higgs and Thomas, 2016).

Menurut penelitian di Minneapolis bahwa teman sangat berpengaruh terhadap kebiasaan konsumsi minum miuman bersoda pada remaja. Selain pengaruh teman akses dan ketersediaan minuman bersoda disekolah memilik peran yang signifikan dalam membentuk kebiasaan konsumsi remaja(Bruening et al., 2014). Remaja menghabiskan sebagian besar waktunya di sekolah. Sekolah memiliki potensi yang menjadi salah satu kesempatan dalam promosi kesehatan. Memanfaatkan lingkungan sekolah juga dapat menjadi cara yang efektif dalam mencapai anak, remaja dan orang tua mereka dalam jumlah yang besar. Untuk itu dibutuhkan sebuah kajian yang melihat bagaiamana penelitian berbasis teman sebaya di sekolah dalam menurunkan konsumsi soft drink remaja

\section{METODE PENELITIAN}

Penelitian ini adalah penelitian eksperimental. Jenis penelitian ini adalah eksperimen faktorial dengan desain $2 \times 2$ yaitu 2 variabel bebas (Pengaruh teman sebaya: ada dan tidak) dengan 2 level perlakuan (Penyediaan air minum: ada dan tidak). Intervensi teman sebaya, intervensi penyediaan air minum, intervensi teman sebaya+air minum dan tidak ada intervene (kelompok Kontrol).

Penelitian dilaksanakan di Kab Bone pada februari-April 2019 dengan jumlah 100 responden berumur 13-15 tahun dan dipilih berdasarkan teknik randomized sampling dalam memilih kelompok intervensi. Pengumpulan data dilakukan melalui pengisian kuesioner sebelum, 4 minggu setelah intervensi dan 2 minggu setelah masa follow up. Data dianalisis menggunakan Stata 13.

\section{HASIL DAN PEMBAHASAN}

\section{Karakteristik Responden}

Sebagian besar resonden adalaah perempuan yang tersebar dimasing-masing kelompok intervensi. Di setiap kelompok intervensi tidak terdapat perbedaan perbandingan jumlah laki-laki dan perempuan secara bermakna. Begitu pula dengan usia responden. Rata-rata usia responden di setiap kelompok intervensi adalah 13 tahun. Status gizi pada masing-masing kelompok intervensi tidak terdapat perbedaan yang bermakna baik status gizi kurus, normal maupun gemuk, namun sebagian besar responden berstatus gizi normal, di setiap kelompok intervensi. Rata-rata uang jajan responden sama di setiap kelompok intervensi, yaitu kisaran Rp 10.525 per hari. Pengetahuan responden terhadapsoft drink cukup tinggi di setiap kelompok

Gambaran konsumsi soft drink sebelum intervensi tidak dipengaruhi oleh karakteristik responden secara signifikan. Baik itu jenis kelamin, umur, status gizi, uang saku, pengetahuan, teman sebaya, keluarga, peraturan, sikap intensi, akses, intensi, pengetahuan air minum, dan sikap terhadap air minum. Namun setelah intervensi terdapat 
variabel lain yang berpengaruh terhadap konsumsi soft drink secara signifikan yaitu pengetahuan, sikap terhadap air, pengetahuan tentang air, keluarga dan teman sebaya (Tabel 2) pengaruh variabel luar ini ditemuka setelah intervensi namun tidak berpengaruh setelah intervensi dihentikan yaitu pada masa follow up. Pengaruh ini lebih signifikan pada kelompok intervensi K3 dibandingkan dengan kelompok control $(\mathrm{p}<0.05)$. Intervensi teman sebaya+ penyediaan air minum yang disertai dengan pengaruh keluarga memiliki pengaruh terhadap konsumsi soft drink responden. Serta pengaruh K1 dan K3 yaitu teman sebaya, teman sebaya+penyediaan air minum disertai pengaruh pengetahuan dan sikap terhadap air terhadap konsumsi soft drink

Konsumsi Soft Drink

Hasil analisis dengan Kruskal Wallis terhadap jumlah konsumsi soft drink pre intervensi menunjukkan tidak ada perbedaan yang signifikan pada semua kelompok ( $p>0.05$ ), sedangkan jumlah konsumsi soft drink post intervensi menunjukkan perbedaan yang signifikan $(\mathrm{p}<0.05)$. Analisis lanjutan dilakukan dengan uji post hoc menggunakan post hoc Kruskal Wallis untuk mengetahui letak perbedaan diantara kelompok intervensi. Hasil analisis menunjukkan bahwa terdapat perbedaan di antara kelompok intervensi teman sebaya disertai pemberian air minum (K3) dengan kelompok kontrol (K4). Hal ini menunjukkan bahwa terdapat perbedaan jumlah konsumsi soft drink antara kelompok yang diberi intervensi teman sebaya +pemberian air minum dengan kelompok yang tidak diberi intervensi atau diberi intervensi teman sebaya saja atau penyediaan air minum saja. Perbedaan perlakuan dapat menghasilkan dampak yang tidak sama.

Tabel 1 Karakteristik Responden

\begin{tabular}{|c|c|c|c|c|c|}
\hline Variabel & $\begin{array}{c}\text { Teman } \\
\text { Sebaya }(\mathbf{K} 1) \\
n=23\end{array}$ & $\begin{array}{c}\text { Air Minum } \\
\qquad \begin{array}{c}\text { (K2) } \\
n=32\end{array}\end{array}$ & $\begin{array}{c}\text { Teman } \\
\text { Sebaya+Air } \\
\text { Minum (K3) } \\
\text { n=23 }\end{array}$ & $\begin{array}{c}\text { Kontrol (K4) } \\
n=21\end{array}$ & $\operatorname{sig}(p)^{1}$ \\
\hline \multicolumn{6}{|l|}{$\begin{array}{l}\text { Jenis Kelamin } \\
(\mathbf{n}, \%)\end{array}$} \\
\hline Laki-laki & $11(47.83)$ & $6(18.75)$ & $8(34.78)$ & $11(47.62)$ & \multirow{2}{*}{0.078} \\
\hline Perempuan & $12(52.17)$ & $26(81.25)$ & $15(65.22)$ & $10(52.38)$ & \\
\hline $\begin{array}{l}\text { Usia, tahun } \\
\text { (Mean } \pm \text { SD) }\end{array}$ & $13.56 \pm 0.506$ & $13.25 \pm 0.439$ & $13.82 \pm 0.387$ & $13.85 \pm 0.654$ & 0.000 \\
\hline \multicolumn{6}{|l|}{$\begin{array}{l}\text { Status Gizi } \\
(\mathrm{n}, \%)\end{array}$} \\
\hline Kurus & $12(52.17)$ & $18(56.25)$ & $15(65.22)$ & $9(42.86)$ & \multirow{3}{*}{0.819} \\
\hline Normal & $10(43.48)$ & $13(40.63)$ & $8(34.78)$ & $11(52.38)$ & \\
\hline Gemuk & $1(4.35)$ & $1(3.13)$ & $0(0-0)$ & $1(4.76)$ & \\
\hline $\begin{array}{l}\text { Uang Saku } \\
(\text { Mean } \pm \text { SD) }\end{array}$ & $9869 \pm 4037.37$ & $11125 \pm 5712.18$ & $9869 \pm 3969.24$ & $11047 \pm 5911.65$ & 0.6933 \\
\hline \multicolumn{6}{|l|}{ Pengetahuan } \\
\hline Cukup & $21(91.30)$ & $30(93.75)$ & 20 (86.96) & $20(95.24)$ & \multirow{2}{*}{0.746} \\
\hline Kurang & $2(8.70)$ & $2(6.25)$ & $3(13.04)$ & $1(4.76)$ & \\
\hline
\end{tabular}




\begin{tabular}{|c|c|c|c|c|c|}
\hline Berpengaruh & $9(39.13)$ & $16(50.00)$ & $12(52.17)$ & $10(47.62)$ & \multirow[b]{2}{*}{0.819} \\
\hline $\begin{array}{l}\text { Tidak } \\
\text { berpengaruh }\end{array}$ & $14(60.87)$ & $16(50.00)$ & $11(52.38)$ & $11(52.38)$ & \\
\hline \multicolumn{6}{|l|}{ Sikap } \\
\hline Berpengaruh & $14(60.87)$ & $18(56.25)$ & $15(65.22)$ & $12(57.14)$ & \multirow[b]{2}{*}{0.915} \\
\hline $\begin{array}{l}\text { Tidak } \\
\text { berpengaruh }\end{array}$ & $9(39.13)$ & $14(43.75)$ & $8(34.78)$ & $9(42.86)$ & \\
\hline \multicolumn{6}{|l|}{ Akses } \\
\hline Dekat & $19(82.61)$ & $29(90.63)$ & $18(78.26)$ & $17(80.95)$ & \multirow{3}{*}{0.317} \\
\hline Menengah & $2(8.70)$ & $1(3.13)$ & $5(21.74)$ & $2(9.52)$ & \\
\hline Jauh & $2(8.70)$ & $2(6.25)$ & - & $2(9.52)$ & \\
\hline \multicolumn{6}{|c|}{ Peran Keluarga } \\
\hline Berpengaruh & $3(13.04)$ & $6(18.75)$ & $9(39.13)$ & $8(38.10)$ & \multirow[b]{2}{*}{0.090} \\
\hline $\begin{array}{l}\text { Tidak } \\
\text { Berpengaruh }\end{array}$ & $20(86.96)$ & $26(81.25)$ & $14(60.87)$ & $13(61.90)$ & \\
\hline \multicolumn{6}{|l|}{ Intensi } \\
\hline Berpengaruh & $13(56.62)$ & $19(59.38)$ & $16(59.57)$ & $14(66.67)$ & \multirow[b]{2}{*}{0.101} \\
\hline $\begin{array}{l}\text { Tidak } \\
\text { Berpengaruh }\end{array}$ & $10(43.48$ & $13(40.63)$ & $7(30.43)$ & $7(33.33)$ & \\
\hline \multicolumn{6}{|l|}{ Pengetahuan } \\
\hline \multicolumn{6}{|l|}{ Air } \\
\hline Kurang & $2(8.70)$ & $4(12.50)$ & $2(8.70)$ & $3(14.29)$ & \multirow{2}{*}{0.908} \\
\hline Cukup & $21(91.30)$ & $28(87.50)$ & $21(91.30)$ & $18(85.71)$ & \\
\hline \multicolumn{6}{|l|}{ Sikap } \\
\hline Berpengaruh & $12(52.17)$ & $12(37.50)$ & $13(56.52)$ & $10(47.62)$ & \multirow[b]{2}{*}{0.525} \\
\hline $\begin{array}{l}\text { Tidak } \\
\text { Berpengaruh }\end{array}$ & $11(47.83)$ & $20(62.50)$ & $10(43.48)$ & $11(52.38)$ & \\
\hline \multicolumn{6}{|l|}{ Peran Teman } \\
\hline \multicolumn{6}{|l|}{ Sebaya } \\
\hline Berpengaruh & $13(56.52)$ & $18(56.25)$ & $15(65.22)$ & $13(61.90)$ & \multirow[b]{2}{*}{0.899} \\
\hline $\begin{array}{l}\text { Tidak } \\
\text { Berpengaruh }\end{array}$ & $10(43.48)$ & $14(43.75)$ & $8(34.78)$ & $8(38.10)$ & \\
\hline
\end{tabular}

Keterangan: Sig $(\mathrm{p})^{1)}=$ Signifikansi antar kelompok dianalisis menggunakan uji Kruskall Wallis, dilanjutkan dengan uji Post Hoc Krukal wallis. Sig $(\mathrm{p})^{2)}=$ Signifikansi antara pre test, post test dan followup menggunakan uji friedman

Tabel 2. Pengaruh Variabel Luar Terhadap Konsumsi Soft Drink

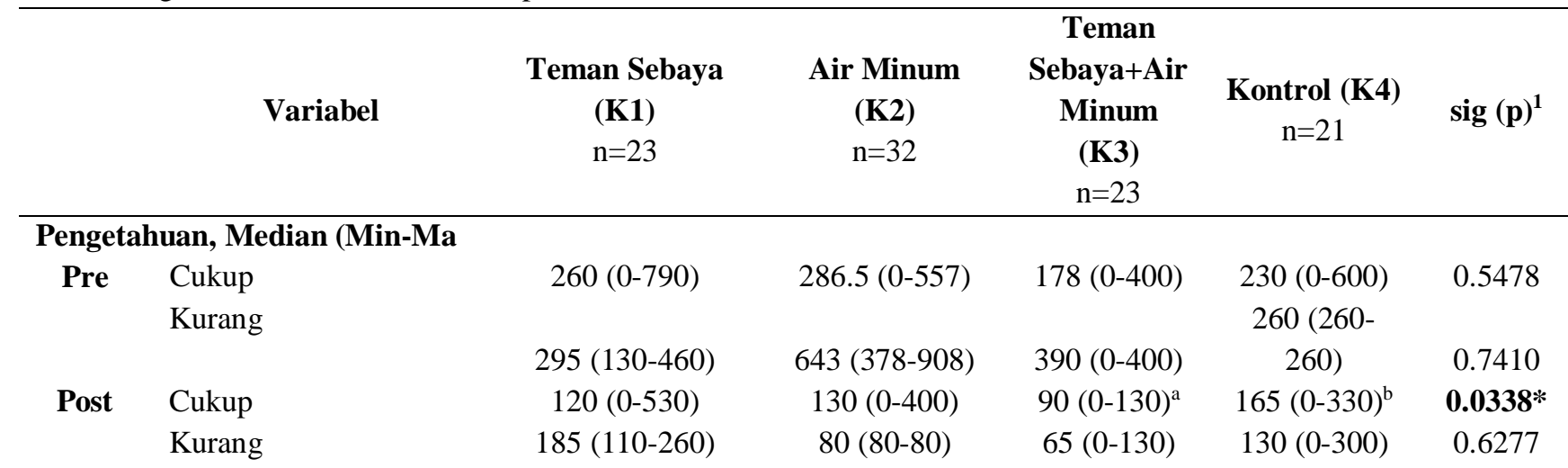




\section{JURNAL BIOLOGY SCIENCE \& EDUCATION 2021 NURWAFIAH MARDA}

\begin{tabular}{|c|c|c|c|c|c|c|}
\hline $\begin{array}{l}\text { Follow } \\
\text { Up }\end{array}$ & $\begin{array}{l}\text { Cukup } \\
\text { Kurang }\end{array}$ & $\begin{array}{l}0(0-220) \\
0(0-0)\end{array}$ & $\begin{array}{c}0(0-178) \\
100(0-200)\end{array}$ & $\begin{array}{c}0(0-130) \\
0(0-0130)\end{array}$ & $\begin{array}{c}0(0-0) \\
0(0-130)\end{array}$ & $\begin{array}{l}0.2527 \\
0.6911\end{array}$ \\
\hline \multicolumn{7}{|c|}{$\begin{array}{l}\text { Pengetahuan Air, Median (Min- } \\
\text { Max) }\end{array}$} \\
\hline \multirow[t]{2}{*}{ Pre } & Kurang & $230(0-460)$ & $254(0-486)$ & $0(0-0)$ & $\begin{array}{l}260(130- \\
400)\end{array}$ & 0.8340 \\
\hline & Cukup & $260(0-790)$ & $305.5(0-908)$ & $200(0-400)$ & $230(0-600)$ & 0.3974 \\
\hline \multirow[t]{2}{*}{ Post } & Kurang & - & $140(80-200)$ & - & $120(0-220)$ & $0.0176 *$ \\
\hline & Cukup & $120(0-530)$ & $130(0-400)$ & $90(0-130)$ & $165(0-330)$ & 1.000 \\
\hline Follow & Kurang & - & $0(0-0)$ & - & $0(0-130)$ & 0.5255 \\
\hline Up & Cukup & $0(0-220)$ & $0(0-200)$ & $0(0-130)$ & $0(0-130)$ & 0.4795 \\
\hline \multicolumn{7}{|c|}{ Sikap Air, Median (Min-Max) } \\
\hline \multirow[t]{2}{*}{ Pre } & Berpengaruh & $189(0-530)$ & 319 (0-908) & $178(0-400)$ & $265(0-600)$ & 0.3387 \\
\hline & Tidak Berpengaruh & $400(0-790)$ & $154(0-557)$ & $243(0-400)$ & $\begin{array}{c}260(130- \\
460)\end{array}$ & 0.4672 \\
\hline \multirow[t]{2}{*}{ Post } & Berpengaruh & $144(0-260)$ & $165(0-400)$ & $90(0-130)^{\mathrm{a}}$ & $130(0-330)^{\mathrm{b}}$ & 0.0384 \\
\hline & Tidak Berpengaruh & $120(0-530)$ & $100(0-230)$ & $85(0-120)$ & $165(0-300)$ & 0.2845 \\
\hline Follow & Berpengaruh & $0(0-0)$ & $0(0-178)$ & $0(0-130)$ & $0(0-130)$ & 0.3557 \\
\hline Up & Tidak Berpengaruh & $0(0-220)$ & $0(0-200)$ & $0(0-130)$ & $0(0-130)$ & 0.6495 \\
\hline \multicolumn{7}{|c|}{$\begin{array}{l}\text { Peran Keluarga, Median (Min- } \\
\text { Max) }\end{array}$} \\
\hline \multirow[t]{2}{*}{ Pre } & Berpengaruh & $308(130-790)$ & $243(0-908)$ & $200(0-400)$ & $300(0-460)$ & 0.9495 \\
\hline & Tidak Berpengaruh & $230(0-530)$ & $316.5(0-557)$ & $178(0-400)$ & $260(0-600)$ & 0.5855 \\
\hline \multirow[t]{2}{*}{ Post } & Berpengaruh & $220(0-530)$ & $120(0-400)$ & $90(0-130)$ & $130(0-330)$ & $0.0110 *$ \\
\hline & Tidak Berpengaruh & $80(0-210)$ & $130(0-330)$ & $85(0-120)$ & $\begin{array}{c}200(130- \\
300)\end{array}$ & 0.0408* \\
\hline Follow & Berpengaruh & $0(0-200)$ & $0(0-178)$ & $0(0-130)$ & $0(0-130)$ & 0.6310 \\
\hline Up & Tidak Berpengaruh & $0(0-220)$ & $0(0-200)$ & $0(0-0)$ & $0(0-0)$ & 0.6327 \\
\hline \multicolumn{7}{|c|}{$\begin{array}{l}\text { Peran Teman Sebaya, Median } \\
\text { (Min-Max) }\end{array}$} \\
\hline \multirow[t]{2}{*}{ Pre } & Berpengaruh & $378(0-790)$ & $130(0-908)$ & $178(0-400)$ & $330(0-600)$ & 0.1121 \\
\hline & Tidak Berpengaruh & $100(0-460)$ & $367(0-557)$ & $319(0-400)$ & $230(0-460)$ & 0.2270 \\
\hline \multirow[t]{2}{*}{ Post } & Berpengaruh & $80(0-260)^{\mathrm{a}}$ & $0(0-400)$ & $85(0-130)^{\mathrm{a}}$ & $165(0-330)^{\mathrm{b}}$ & $0.0245^{*}$ \\
\hline & Tidak Berpengaruh & $260(200-530)$ & $130(0-330)$ & $\begin{array}{c}110(110- \\
110)\end{array}$ & $130(0-300)$ & 0.0696 \\
\hline Follow & Berpengaruh & $0(0-220)$ & $0(0-178)$ & $0(0-130)$ & $0(0-130)$ & 0.3123 \\
\hline Up & Tidak Berpengaruh & $0(0-200)$ & $0(0-200)$ & $0(0-0)$ & $0(0-130)$ & 0.8312 \\
\hline
\end{tabular}

Keterangan: Sig $(\mathrm{p})^{1)}=$ Signifikansi antar kelompok dianalisis menggunakan uji Kruskall Wallis, dilanjutkan dengan uji Post Hoc Krukal wallis. Sig $(\mathrm{p})^{2)}=$ Signifikansi antara pre test, post test dan followup menggunakan uji friedman ${ }^{a, b, c, d)}=$ Abjad yang tidak sama menunjukkan signifikansi hasil uji Post Hoc, p<0.05. *Pengaruh Pengetahuan terhdap Konsumsi soft drink post intervensi cukup: K3-K4(0.0004). Pengaruh sikap air terhadap konsumsi soft drink K3-K4 berpengaruh (0.0091) 


\section{JURNAL BIOLOGY SCIENCE \& EDUCATION 2021 NURWAFIAH MARDA}
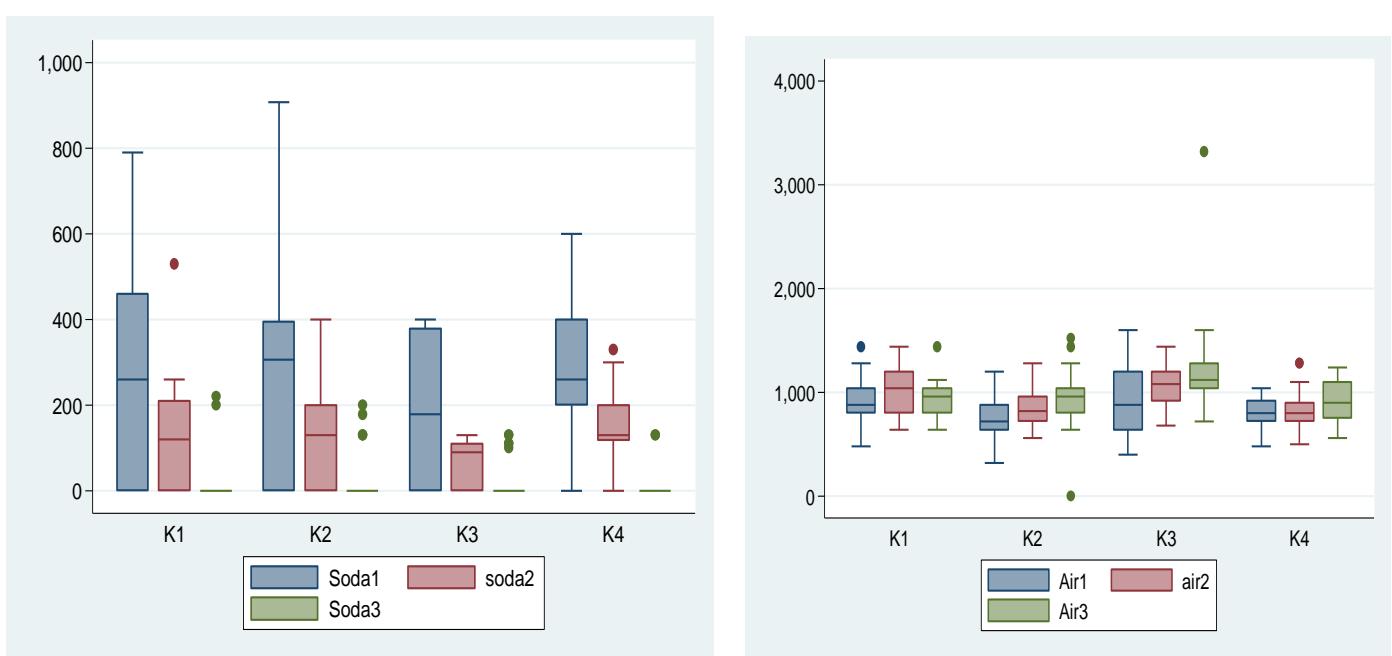

A

B

Gambar 1. (A). Pengaruh Intervensi Terhadap Konsumsi Soda, (B). Pengaruh Intervensi Terhadap Konsumsi Air Minum

Tabel 3 Gambaran Konsumsi Soft Drink

\begin{tabular}{|c|c|c|c|c|c|}
\hline Variabel & $\begin{array}{c}\text { Teman Sebaya }(\mathbf{K 1}) \\
\mathrm{n}=23\end{array}$ & $\begin{array}{c}\text { Air Minum } \\
\qquad \begin{array}{c}\text { (K2) } \\
n=32\end{array}\end{array}$ & $\begin{array}{c}\text { Teman } \\
\text { Sebaya+Air } \\
\text { Minum (K3) } \\
\text { n=23 }\end{array}$ & $\begin{array}{c}\text { Kontrol (K4) } \\
n=21\end{array}$ & $\operatorname{sig}(p)^{1}$ \\
\hline \multicolumn{6}{|l|}{ Konsumsi } \\
\hline \multicolumn{6}{|l|}{$\begin{array}{l}\text { Soft Drink, } \\
\text { Median } \\
\text { (Min-Max) }\end{array}$} \\
\hline Pre & $260(0-790)$ & $305.5(0-908)$ & $178(0-400)$ & $260(0-600)$ & 0.6481 \\
\hline Post & $120(0-530)$ & $130(0-400)$ & $90(0-130)^{\mathrm{a}}$ & $130(0-330)^{\mathrm{b}}$ & $0.0212 *$ \\
\hline Follow up & $0(0-220)$ & $0(0-200)$ & $0(0-130)$ & $0(0-130)$ & 0.676 \\
\hline $\operatorname{Sig}(p)^{2}$ & 0.0689 & $0.0102 *$ & $0.0045^{*}$ & 0.2090 & \\
\hline \multicolumn{6}{|l|}{$\begin{array}{l}\text { Air Minum, } \\
\text { Median } \\
\text { (Min-Max) }\end{array}$} \\
\hline Pre & $880(480-1440)$ & $720(320-1200)$ & $880(400-1600)$ & $800(480-1040)$ & 0.1871 \\
\hline Post & $1040(640-1440)^{\mathrm{a}}$ & $820(560-1280)$ & $1080(680-1440)^{\mathrm{a}}$ & $800(500-1280)^{b}$ & $0.0005 *$ \\
\hline Follow up & $960(640-1440)$ & $960(0-1520)$ & $1120(720-3320)^{\mathrm{a}}$ & $900(560-1240)^{\mathrm{b}}$ & $0.0013 *$ \\
\hline $\operatorname{Sig}(p)^{2}$ & $0.0048 *$ & 0.3092 & 0.7966 & $0.0015 *$ & \\
\hline
\end{tabular}

Keterangan:

Data tidak terdistribusi normal. Sig $(\mathrm{p})^{1)}=$ Signifikansi antar kelompok dianalisis menggunakan uji Kruskall Wallis, dilanjutkan dengan uji Post Hoc Krukal wallis. Sig $(\mathrm{p})^{2)}=$ Signifikansi antara pre test, post test dan follow-up menggunakan uji friedman. Sig $(\mathrm{p})^{3)}=$ Signifikansi antar Kelompok dianalisismenggunakan uji Kolmogorov Smirnov. ${ }^{\text {a,b,c,d) }}=$ Abjad yang tidak sama menunjukkan signifikansi hasil uji Post Hoc, 
p $<0.05$. *Konsumsi soft drink post intervensi: K3-K4 (0.0003). Konsumsi air minum post intervensi: K1K4 (0.0232), K3-K4 (0.0007). Follow-up Konsumsi air minum: K3-K4 (0.0017). * Konsumsi soft drink Pre-post K2 (0.000), pre-post K3 (0.0001) Konsumsi soft drink Post-follow up K2(0.0001).post-followup K3 (0.0011). Konsumsi air minum pre-post K4(0.0498), konsumsi air minum post-follow up K4 (0.0001)

Hasil analisis Friedman terhadap jumlah konsumsi soft drink sebelum dan sesudah pemberian intervensi menunjukkan perbedaan yang signifikan $(\mathrm{p}=0.0045)$ pada kelompok intervensi penyediaan air minum serta intervensi teman sebaya+penyediaan air minum. Terdapat perbedaan yang bermakna konsumsi soft drink sebeum intervensi dan setelah intervensi serta setelah follow up dikelompok kedua kelompok intervensi tersebut.

\section{Konsumsi Air Minum}

Tidak ada perbedaan yang signifikan terhadap konsumsi air minum pada semua kelompok ( $>0$ 0.05), sedangkan jumlah konsumsi air minum post intervensi menunjukkan perbedaan yang signifikan $(\mathrm{p}<0.05)$. Analisis lanjutan menunjukkan bahwa kelompok intervensi teman sebaya (K1) dan teman sebaya+pemberian air minum (K3) memiliki perbedaan yang signifikan dengan kelompok kontrol (K4). Hal ini menunjukkan terdapat perbedaan jumlah konsumsi air minum antara kelompok yang diberi intervensi teman sebaya saja dan intervensi teman sebaya+pemberian air minum dengan kelompok kontrol. Pada masa follow up perbedaan konsumsi soft drink signifikan pada kelompok intervensi K3. Jumlah konsumsi soft drink sebelum dan sesudah diberikan intervensi menunjukkan perbedaan yang signifikan $(\mathrm{p}<0.05)$ pada kelompok intervensi K4. Sedangkan jumlah konsumsi sesudah dan follow up terdapat perbedaan pada intervensi K4.

1. Faktor yang berhubungan dengan konsumsi air minum

Faktor-faktor yang mempengaruhi konsumsi soft drink setelah intervensi adalah pengetahuan, keluarga, teman sebaya, pengetahuan tentang air minum dan sikap terhadap air minum. Terdapat perbedaan konsumsi soft drink secara signifikan pada kelompok intervensi teman sebaya disertai dengan penyediaan air minum (K3) bila dibandingkan dengan kelompok intervensi lain. Sedangkan faktor yang mempengaruhikonsumsi air minum adalah pengetahuan, peraturan, sikap, pegetahuan tentang air, sikap terhadap air, akses, keluarga, intensi dan teman sebaya. Pada kelompok intervensi K3 dibandingkan dengan kelompok lain. Menurut hasil penelitian, intervensi berbasis teman sebaya merupakan intervvensi yang efektif dalam merubah perilaku dalam waktu singkat (Lien et al., 2014).

Sejalan dengan hasil penelitian frekuensi konsumsi soft drink terutama dipengaruhi oleh orang tua dan pengaruh teman sebaya dan memiliki dampak yang signifikan terhadap konsumsi soft drink anak. Begitu pula dengan konsumsi air minum, intervensi teman sebaya disertai penyediaan air minum memberikan pengaruh terhadap pengetahuan, sikap, pengetahuan tentang air minum(Pettigrew et al., 2015).

Sejalan dengan penelitian, menyebutkan bahwa role model, dan sikap merupakan determinan yang berpengaruh paling kuat terhadap konsumsi soft drink (McDermott et al., 2015). Menurut teori social cognitive model khususnya Teori Perilaku yang 
Direcanakan atau lebih sering disebut sebagai Theory of Planned Behaviour (Ajzen, 1991), yang sering digunakan untuk menjelaskan perilaku makan. Teori ini menjelaskan bahwa perilaku dapat dapat diprediksi dari keinginan untuk melakukan kebiasaan tertentu dan oleh persepsi mengenai kemudahan atau kesulitan dalam melakukan perilaku dimana perilaku tersebut juga ditentukan oleh sikap, norma subjektif(Gregorio-Pascual and Mahler, 2020).

Penelitian terbaru menyebutkan bahwa faktor lingkungan yang didefenisiskan sebagai ketersediaan, aksesibilitas (lingkungan fisik), kelayakan dan dukungan sosial (lingkungan sosial budaya), serta undang-undang, peraturan, dan kebijakan (lingkungan politik) memiliki peran penting dalam pemilihan makanan dan perilaku makan yang dijelaskan dalam teori Ecological Behavior Model(Sleddens et al., 2015).

Niat/intensi dianggap sebagai konsekuensi dari motivasi. Setiap teori memiliki perbedaan namun hampir sama tentang intensi sebagai determinan paling penting dalam perilaku. Berdasarkan teori-teori yang telah disebutkan sebelumnya, determinan yang berpengaruh dalam memprediksi niat adalah sikap, tampilan diri, keyakinan diri, dan pengaruh sosial(Gregorio-Pascual and Mahler, 2020).

Menurut Santrock mengatakan bahwa peran penting teman sebaya dalah sebagai sumber informasi dan kognitif mengenai dunia di luar keluara dan sumber untuk pemecahan masalah dan perolehan pengetahuan. Banyak tidaknya perolehan pengetahuan mempengaruhi periaku. Sebagai sumber pengetahuan teman sebaya berperan dalam memberikan informasi baru kepada remaja yang dapatmerubah sikap, intensi dan diaplikasikan dalam bentuk sebuah perilaku minum soft drink maupun minum air.

Menurut teori S-O-R (Woodworth, 1928), stimulus yang diberikan pada remaja oleh agen dapat diterima atau ditolak. Bila stimulus tersebut diteerima oleh remaja berarti ada perhatian pengertian dan penerimaan dari remaja tersebut dengan kata lain stimulus efektif. Stimulus yang diberikan oleh agen berupa edukasi teman sebaya, modeling dengan membawa air setiap hari kesekolah dengan botol air minum, atau mengisi ulang air minum di kelas, ajakan mengkonsumsiair dibandingkan dengan soft drink. bila stimulus diterima akanterlihat dengan perubahan sikap dari remaja, akhirnya denga dukungan fasilitas dalam hal ini penyediaan air minum mempunyai efek tindakan dari remaja (perubahan perilaku). Sesuai dengan penelitian terdapat perubahan sikap, intensi dan perilaku remaja terhadap setelah intervensi oleh age yang disertaidengan penyediaan air minumyang berdampak pada perubahan konsumsi soft drink dan air minum.

Bentuk perubahan perilaku yang dirancang secara alamiah dengan menggunakan pendekatan dan persuasi melalui teman sebaya (agen) serta memfasilitasi dengan menyediakan sarana dan prasarana yang mendukung. Ketika ada rangsangan melalui pengetahuaan dan persuasi dari agen kepada remaja yang akan membentuk intensi pada remaja ditunjukkan dalam perubahan perilaku konsumsi soft drink dan air minum, peningkatan pengetahuandan sikap. 
2. Pengaruh teman sebaya terhadap konsumsi soft drink dan air minum

Pada saat setelah intervensi terjadi penurunan konsumsi soft drink pada kelompok ini namun tidak signifikan bila dibandingkan dengan kelompok kontrol.hal ini menunjukkan bahwa intervensi berupa pengaruh teman sebaya saja tidak efektif dalam menurunkan konsumsi soft drink baik pada periode setelah intervensi maupun pada periode follow-up.

Sejalan dengan penelitian Wouters, menunjukkan bahwa remaja yang memiliki teman dengan konsumsi snack yang tinggi juga akan mengkonsumsi snack lebih banyak bila ketersediaan snack juga tinggi dengan kata lain konsumsi snack individu tidak hanya ditentukan oleh konsumsi snack group temannya namun juga ketersediaan. Penelitian ini menunjukkan bahwa konsumsi makanan ringan dan soft drink individu berhubungan dengan kombinasi spesifik dari konsumsi teman sebaya, ketersediaan di sekolah dan karakteristik personal (umur, jenis kelamin, tingkat pendidikan, BMI) (Wouters et al., 2010). Hal ini menunjukkan bahwa untuk menurunkan konsumsi soft drink remaja tidak cukup hanya dengan pengaruh teman sebaya namun perlu dukungan dari faktor lain seperti ketersediaan dan akses terhadap soft drink (Bruening et al., 2014)

Konsumsi air minum pada kelompok ini, sebaliiknya mengalami peningkatan secara signifikan, $(\mathrm{p}<0.05)$. Peningkatan konsumsi air minum terjadi setelah intervensi dan pada saat periode follow up secara signifikan. Hal ini sejalan dengan penelitian sebelumnya bahwa anak meniru (model) perilaku makan teman sebaya mereka (modelling, social norms). Remaja dapat mengkonsumsi makanan lebih banyak atau lebih sedikit berdasarkan norma sosial yang ditetapkan oleh teman sebaya. Menurut penelitian sebelumnya menunjukkan bahwa dorongan dari teman sebaya dapat meningkatkan penerimaan konsumsi makanan (Hendy et al., 2002; Horne et al., 2011). Sesuai dengan hasil penelitian yang menunjukkan bahwa agen berhasil memberikan pengaruh dalam meningkatkan konsumsi air minum secara signifikan serta penurunan konsumsi soft drink meskipun tidak signifikan bila dibandingkan dengan kontrol.

Penelitian oleh Smit, et al yang melihat pengaruh teman sebaya dalam mempromosikan konsumsi air minum menunjukkan bahwa teman sebaya yang berperan sebagai agen dapat mempengaruhi temannya dalam meningkatkan konsumsi air minum dan menurunkan konsumsi soft drink. berbagai penelitian eksperimen yang memodifikasi perilaku makan melalui lingkungan sosial menemukan efek yang signifikan terhadap perilaku makan baik pemilihan makanan maupun asupan makanan (Smit et al., 2016).

\section{Pengaruh Penyediaan air minum terhadap konsumsi soft drink dan air minum}

Intervensi penyediaan air minum memberikan dampak terhadap konsumsi soft drink responden. Intervensi ini berpengaruh positif terhadap perubahan perilaku remaja. Pada kelompok ini terdapat perbedaan yang bermakna antara konsumsi soft drink pada pre-post intervensi dan post-follow up. perbedaan selisih konsumsi soft drink antar kelompok pada periode pre-post menunjukkan bahwa intervensi penyediaan air minum gratis pada kelompok 2 merupakan intervensi yang memberikan perubahan yang 
bermakna pada penurunan konsumsi soft drink bahkan sampai periode intervensi selesai (periode follow up) bila dibandingkan dengan intervensi lain. Menurut Lally intensitas dalam suatu perilaku akan meningkatkan keotomatisan dalam berperilaku (Lally et al., 2010).

Seuai dengan penelitian sebelumnya yang menilai keefektifan intervene yang berbasis sekolah dan masyarakat dalam menurunkan konsumsi soft drink melalui promosi minum air pada anak sekolah. Hasilnya menunjukkan hubungan positif yang signifikan antara penurunan konsumsi soft drink dengan intervensi. Penelitian ini menunjukkan bahwa promosi minum air efektif dalam menunrunkan konsumsi soft drink dan meningkatkan konsumsi air minum(van de Gaar et al., 2014) Penelitian yang juga melihat pengaruh intervensi penyediaan air minum dan promosi air terhadap konsumsi air dan soft drink anak sekolah menunjukkan bahwa intervensi penyediaan air minum saja tidak dapat meningkatkan konsumsi air minum anak sekolah namun kombinasi intervensi penyediaan air minum disertai dengan promosi aktif tentang air minum dapat meningkatkan konsumsi air minum anak sekolah (Loughridge and Barratt, 2005).

Konsumsi soft drink menurun namun konsumsi air tetap tidak berbeda secara signifikan, hal ini kemungkinan dikarenakan pola minumnya bergeser ke minuman berpemanis bukan minuman soft drink, sehingga terhitung menurun tetapi minuman berpemanis yang justru meningkat. Menurut hasil survey yang melihat pola konsumsi minuman berpemanis dan minuman bersoda di Amerika Serikat menyatakan bahwa prevalensi remaja yang mengkonsumsi minuman bersoda menurun sedangkan prevalensi remaja yang mengkonsumsi minuman berpemanis meningkat 3 kali lipat dari tahun-tahun sebelumnya (1999-2008) (Powell and Han, 2013).

\section{Pengaruh teman sebaya dan penyediaan air minum terhadap konsumsi soft drink dan air minum}

Terdapat perbedaan yang signifikan terhadap perubahan konsumsi soft drink pada kelompok yang mendapatkan intervensi teman sebaya disertai dengan pemberian air minum dibandingkan dengan kelompok yang hanya mendapatkan intervensi dari teman sebaya. Sesuai dengan penelitian sebelumnya bahwa pengaruh dari teman sebaya disertai dengan lingkungan yang mendukung dapat menurunkan konsumsi soft drink remaja.

Penelitian pada anak keturunan Afrika-Amerika, Eropa-Amerika, dan MeksikoAmerika menunjukkan bahwa bukan hanya intensi yang berpengaruh dalam perilaku konsumsi makanan, namun ketersediaan, aksesibilitas, TV pengaruh teman sebaya dan orang tua merupakan faktor penting dalam konsumsi makanan rendah lemak (Cullen et al., 2000). Bahkan penelitian di Australia, menyebutkan bahwa lingkungan sosial budaya (tekanan dan norma sosial) memberikan pengaruh langsung terhadap perilaku konsumsi soft drink remaja (Pettigrew et al., 2015)).Berdasarkan hal tersebut dapat dilihat bahwa intervensi selama 4 minggu meningkatkan pengetahuan namun tidak mengubah perilaku responden.

Berdasarkan penelitian anak umur 9-13 tahun yang konsumsi air minumnya 
distimulasi oleh teman sebaya akan meminumblebih banyak air minum dan rendah minuman bersoda dan berpemanis khususnya ketika teman sebaya yang mempengaruhi itu adalah anak yang di hormati, yang akan ditiru, yang dicari, yag akan dimintai saran dan dianggap sebagai pemimpin yang baik (Smit et al., 2016).

Menurut strategi dengan multi level (menggabungkan antara faktor personal dan lingkungan) merupakan langkah yang lebih efektif bila dibandingkan dengan intervensi hanya dengan satu tingkat an atau satu faktor saja. Sehingga dengan memfokuskan pada mekanisme psikologi, lingkungan siswa (sosial maupun fisik) akan lebih berpengaruh. Dengan kata lain intervensi untuk menurunkan konsumsi soft drink harus menyediakan lingkungan yang mendukung dimana siswa dan teman sebayanya di doronng untuk memilih konsumsi minuman yang lebih sehat. Oleh karena itu berbagai pihak (siswa, orang tua, sekolah dan pembuat kebijakan) harus terlibat dalam menentukan strategi yang lebih baik dalam menentukan tindakan preventif dalam konsumsi soft drink.

\section{KESIMPULAN}

Intervensi penyediaan air putih dan intervensi teman sebaya disertai penyediaan air putih merupakan intervensi yang paling berpengaruh dalam menurunkan konsumsi soft drink remaja. Intervensi teman sebaya merupakan intervensi yang paling berpengaruh dalam meningkatkan jumlah konsumsi air remaja.

\section{SARAN}

Penelitian berbasis sekolah dan intervensi teman sebaya dalam penelitian selanjutnya perlu melakukan kontrol terhadap agen dalam melaksanakan tugas yang dibebankan oleh peneliti dalam penelitian yang berbasis agen serta melakukan follow up. Sedangkan untuk pembuat kebijakan dapat dengan merancang suatu program dalam memberdayakan siswa untuk mempromosikan konsumsi air minum dan mengurangi konsumsi soft drink serta mengajak teman yang lain dalam perilaku sehat tersebut.

\section{DAFTAR PUSTAKA}

Ajzen, I. (1991) 'The theory of planned behavior', Orgnizational Behavior and Human Decision Processes, 50, pp. 179-211. doi: 10.1016/0749-5978(91)90020-T.

Anand, S. S. et al. (2015) 'Food Consumption and its Impact on Cardiovascular Disease: Importance of Solutions Focused on the Globalized Food System A Report from the Workshop Convened by the World Heart Federation', Journal of the American College of Cardiology, 66(14), pp. 1590-1614. doi: 10.1016/j.jacc.2015.07.050.

Bruening, M. et al. (2014) 'Associations Between Sugar-Sweetened Beverage Consumption and Fast-Food Restaurant Frequency Among Adolescents and Their Friends', Journal of Nutrition Education and Behavior, 46(4), pp. 277-285. doi: 10.1016/j.jneb.2014.02.009.

Cullen, K. W. et al. (2000) 'Social-environmental influences on children's diets: results 
from focus groups with African-, Euro- and Mexican-American children and their parents.', Health education research, 15(5), pp. 581-590. doi: 10.1093/her/15.5.581.

van de Gaar, V. M. et al. (2014) 'Effects of an intervention aimed at reducing the intake of sugar-sweetened beverages in primary school children: a controlled trial', International Journal of Behavioral Nutrition and Physical Activity, 11(1), p. 98. doi: 10.1186/s12966-014-0098-8.

Gregorio-Pascual, P. and Mahler, H. I. M. (2020) 'Effects of interventions based on the theory of planned behavior on sugar-sweetened beverage consumption intentions and behavior', Appetite, 145(August 2018). doi: 10.1016/j.appet.2019.104491.

Hendy, H. M. et al. (2002) 'Effectiveness of trained peer models to encourage food acceptance in preschool children', pp. 217-225. doi: 10.1006/appe.2002.0510.

Higgs, S. and Thomas, J. (2016) 'Social influences on eating', Current Opinion in Behavioral Sciences, 9, pp. 1-6. doi: 10.1016/j.cobeha.2015.10.005.

Horne, P. J. et al. (2011) 'Increasing pre-school children's consumption of fruit and vegetables. A modelling and rewards intervention', Appetite. Elsevier Ltd, 56(2), pp. 375-385. doi: 10.1016/j.appet.2010.11.146.

Imamura, F. et al. (2016) 'Consumption of sugar sweetened beverages, artificially sweetened beverages, and fruit juice and incidence of type 2 diabetes: Systematic review, meta-analysis, and estimation of population attributable fraction', British Journal of Sports Medicine, 50(8), pp. 496-504. doi: 10.1136/bjsports-2016h3576rep.

Lally, P. et al. (2010) 'How Habit Are Formed : Modelling Habit Formation in The Real World', European Journal of Social Psychology Eur., 40(June 2009), pp. 625-634. doi: 10.1002/ejsp.

Lien, N. et al. (2014) 'The school nutrition environment and its association with soft drink intakes in seven countries across Europe--the ENERGY project.', Health \& place, 30, pp. 28-35. doi: 10.1016/j.healthplace.2014.07.013.

Loughridge, J. L. and Barratt, J. (2005) 'Does the provision of cooled filtered water in secondary school cafeterias increase water drinking and decrease the purchase of soft drinks?', Journal of Human Nutrition and Dietetics, 18(4), pp. 281-286. doi: 10.1111/j.1365-277X.2005.00622.x.

McDermott, M. S. et al. (2015) 'The theory of planned behaviour and discrete food choices: A systematic review and meta-analysis', International Journal of Behavioral Nutrition and Physical Activity. International Journal of Behavioral Nutrition and Physical Activity, 12(1). doi: 10.1186/s12966-015-0324-z.

Pettigrew, S. et al. (2015) 'Factors influencing the frequency of children's consumption of soft drinks', Appetite, 91, pp. 393-398. doi: 10.1016/j.appet.2015.04.080.

Powell, L. M. and Han, E. (2013) 'Consumption Patterns of Sugar Sweetened Beverages in the United States', Academy of Nutrition and Diet, 113(1), pp. 43-53. doi: 
10.1016/j.jand.2012.09.016.CONSUMPTION.

PUSLITBANG Upaya Kesehatan Masyarakat (2015) 'Perilaku Berisiko Kesehatan pada Pelajar SMP dan SMA di Indonesia', Badan Litbangkes Kementrian Kesehatan RI, pp. 1-116. Available at: http://www.who.int/ncds/surveillance/gshs/GSHS_2015_Indonesia_Report_Bahas a.pdf?ua=1.

Sakurai, M. et al. (2014) 'Sugar-sweetened beverage and diet soda consumption and the 7 -year risk for type 2 diabetes mellitus in middle-aged Japanese men', European Journal of Nutrition, 53(1), pp. 251-258. doi: 10.1007/s00394-013-0523-9.

Sleddens, E. F. C. et al. (2015) 'Determinants of dietary behavior among youth: an umbrella review', International Journal of Behavioral Nutrition and Physical Activity, 12(7). doi: 10.1186/s12966-015-0164-x.

Smit, C. R. et al. (2016) 'A social network-based intervention stimulating peer influence on children's self-reported water consumption: A randomized control trial', Appetite. Elsevier Ltd, 103, pp. 294-301. doi: 10.1016/j.appet.2016.04.011.

Storey, M. (2010) 'The shifting beverage landscape', Physiology and Behavior. Elsevier Inc., 100(1), pp. 10-14. doi: 10.1016/j.physbeh.2010.02.009.

Wolk, A., Larsson, S. C. and Agneta, A. (2014) 'Sweetened Beverage Consumption Is Associated with Increased Risk of Stroke in Women and Men', The Journal of nutrition, 144(6), pp. 856-860. doi: 10.3945/jn.114.190546.reported.

Wouters, E. J. et al. (2010) 'Peer influence on snacking behavior in adolescence §', Appetite. Elsevier Ltd, 55(1), pp. 11-17. doi: 10.1016/j.appet.2010.03.002. 